UDC 615

DOI: $10.15587 / 2519-4798.2018 .135132$

\title{
BIO-BASED SUCCINIC ACID SAMPLE PREPARATION AND DERIVATIZATION PROCEDURE OPTIMISATION FOR GAS CHROMATOGRAPHY-MASS SPECTROMETRY ANALYSIS
}

\author{
(C) L. Jarukas, J. Kamarauskaitė, M. Marksa, S. Trumbeckaitė, R. Banienė, L. Ivanauskas
}

У цьому дослідженні основна увага була приділена отримання зразків бурштинової кислоти з біологічної
сировини і умов оптимізації отримання похідних з використанням методу ГХ-МС. Бурштинова кислота,
попередник широкого діапазону біологічних сполук, особливо важлива для накопичення метаболіту мі-
тохондрій сукцината (цикл лимонної кислоти), а під час ішемї̈ контролює реперфузійне пошкодження
за допомогою продукування мітохондріального реактивного кисню. Точне визначення речовини для ана-
лізу є ключовим в метаболоміці для використання в якості низькомолекулярних біомаркерів в разі поліп-
шення діагностичних методів.

Методи. Метод газової хромато-мас-спектрометрї (ГХ-МС). Для кількісного визначення використаного прочесу дериватизації бурштинової кислоти иляхом силілювання з використанням -біс- (триметилсиліл) -трифторацетаміда (BSTFA).

Результати. Дериватизатор BSTFA, час дериватизації 3-4 години і температура дериватизації $70{ }^{\circ} \mathrm{C}$ були обрані в якості оптимальних умов прочесу для кількісного визначення бурштинової кислоти методом ГХ-МС в біологічних зразках. Результати показують, щчо метод ГХ-МС СДІ з випаровуванням найбільш ефективний для кількісного визначення сукиината в біологічних зразках після ішемії / реперфузійного ушкодження. Селективне детектування іонів (СДI) дозволило контролювати підмножина фрагментів зі зв'язаними значеннями маси в певному діапазоні часу утримування (RT) для набору цілей.

Висновки. ГХ-МС має кілька переваг для вимірювання конщентрації сукцинату в невеликих зразках тканин нирки (ліофілізовані мітохондрії). Метод може бути застосований в невеликих шиаточках тканини - зразки біопії, тканини з різних органів

Ключові слова: бурштинова кислота, газова хромато-мас-спектрометрія, дериватизація, BSTFA, метаболоміка, ГХ-МС

\section{Introduction}

At present, gas chromatography-mass spectrometry (GC-MS) platforms are frequently used method for identification and quantitation analysis of low molecular analytes to provide the sensitive and reproducible detection of compounds [1]. However, not all chromatographic methods are suitable for the given analytical targets. The GC-MS analysis of nonvolatile and thermally labile analytes is based on applying chemical modifications so called derivatization procedure. Chemical derivatization is used when the properties of target analytes are not compatible with the analytical procedure, when detection is not sufficiently sensitive or selective. After application the analyte becomes more polished and has lower polarity, which increases the detection limit of the compounds and analytical resolution. Generally, derivatization is aimed to improve suitability, efficiency and detectability aspects in Gas Chromatography [1]. Sequentially separated compounds of analyte during derivatization procedure can substantially improve chromatographic results and allow to make assumptions for further research studies. Although, manually derivatization methods require knowledge of analyte preparation step and therefore ability to analyze solutions directly would be of significant benefit $[2,3]$.

This study focused on bio-based succinic acid sample preparation and derivatization conditions optimization using GC-MS analytical method. Succinic acid, the precursor of a wide range bio-compounds, especially it is important in accumulation of mitochondrial metabolite succinate (citric acid cycle) and during ischemia controls reperfusion injury through mitochondrial reactive oxygen production.

2. Formulation of the problem in a general way, the relevance of the theme and its connection with important scientific and practical issues

Accurate determination of analytes is the key in metabolomics to use as low molecular biomarkers in case to improve diagnostic methods. GC-MS platforms are widely used but a significant proportion of short-chain monocarboxylic acids (fatty acids, sterols, amino acids and other organic acids) are volatile and thus may be lost together with the solvent, which might lead to underestimation of their structure and cannot be accurately investigated. Derivatized analyte samples are more volatile and stable with a smaller number of polar groups.

Therefore, several options are available as for selecting the derivatization type and pre-analytical sample procedures for GC-MS analysis of different compounds. In addition, stable analyte result leads low detector noise and fouling. Finally, the effectiveness of the chromatography process is relevant on the small concentrations of target biological tissues using for experimental research.

3. Analysis of recent studies and publications in which a solution of the problem are described and to which the author refers

In recent decade advancements in analytical research and data analysis improvements, molecular detection has been improved tremendously. Nowadays opportunities let to detect and identify thousands of metabolites in a very short time [4]. In metabolomics, the goal is 
to improve analytical suitability, efficiency and detectability aspects from a biological specimen. Using efficient interpretation of these pre-analytical models, also could be useful involving biomarkers identification to diseases [5]. The synergistic coupling of GC and MS renders the tandem technique a major analytical workhorse in metabolomics [6]. Considering techniques such as GCMS without derivatization procedure can analyse up to several hundred components with structures so-called 'fingerprinting' techniques where the extract is spectroscopically analysed may prove to be more useful [7, 8]. The preparation and evaluation of analytes would be evaluated of analytical approach. A correctly obtained derivatization procedure, based on the chemical composition of the target analytes, can significantly improve chemical separations. Suitable derivatization conditions, such as derivatization reagent, extraction conditions must be selected to avoid secondary derivatives and increase stability [9].

Alkylation and silylation are most used derivatization type protocols in low molecular analytes and metabolite profiling of many methods. Silylation method replace the active hydrogen $(-\mathrm{OH},-\mathrm{SH},-$ $\mathrm{NH} 4+,-\mathrm{COOH})$ with a silyl group $[-\mathrm{Si}(\mathrm{CH} 3) 3-]$ in case to increase analyte stability and volatility. Silylation could be described as safe, easy to commonly use and simple reaction stages are required. The classical silylation reagents are N,O-bis(trimethylsilyl) trifluroacetamide (BSTFA) and N-Methyl-N-(trimethylsilyl) trifluoroacetamide (MSTFA) [10, 1]. The reagents for silylation are required anhydrous conditions because of sensitivity of moisture. Sometimes, during the preparation of analytes it is difficult to reach complete dryness of compounds [10].

Ischemia-reperfusion injury occurs when the blood supply to an organ is disrupted and then restored, and underlies many disorders, notably heart attack and stroke [11]. Several studies indicate that accumulation of mitochondrial metabolite succinate (citric acid cycle intermediate) during ischemia could be involved in reperfusion injury through mitochondrial reactive oxygen production $[12,13]$. In-vivo, succinic acid takes the form of an anion, succinate, which has multiple biological roles as a metabolic intermediate being converted into fumarate by the enzyme succinate dehydrogenase in complex II of the electron transport chain which is involved in making ATP, and as a signaling molecule reflecting the cellular metabolic state [14].

\section{The field of research considering the general problem, which is described in the article}

Despite the large number of analytical research improvements in GC-MS analysis, there are lack of investigations on specific methodology improvements using BSTFA reagents which would lead to identify succinic acid in organic compounds complex. A correctly obtained derivatization procedure and conditions can be used for rapid comparison of large sets of GC-MS data. The important role of right methodology creation and usage in these techniques is required.

\section{Formulation of goals (tasks) of article}

To evaluate bio-based succinic acid sample preparation methodology and chemical derivatization procedure for quantity and identity evaluation using GC-MS analysis.

\section{Presentation of the main research material (methods and objects) with the justification of the results}

The experimental procedures used in the present study were performed according to the permission of the Lithuanian Committee of Good Laboratory Animal Use Practice (No. G2 - 52 (2017)). Wistar rats weighing 200$250 \mathrm{~g}$ were housed under standard laboratory conditions and maintained on natural light and dark cycle and had free access to food and water. Animals were acclimatized to laboratory conditions before the experiment. Then animals were sacrified, kidneys were removed, washed free of blood in cold $\left(0-4{ }^{\circ} \mathrm{C}\right) 0.9 \% \mathrm{KCl}$ solution. After that time, kidney tissue was used for isolation of mitochondria.

Kidney tissue was cut into small pieces and homogenized in the medium containing $250 \mathrm{mM}$ sucrose, $10 \mathrm{mM}$ Tris HCl, $1 \mathrm{mM}$ EDTA (pH 7.3). Cytosolic and mitochondrial fractions were separated by differential centrifugation ( $5 \mathrm{~min}$ at $750 \mathrm{x} \mathrm{g}$ and $10 \mathrm{~min}$ at $10000 \mathrm{x} \mathrm{g}$ ) and pellet was suspended in the isolation medium.

Isolated kidney mitochondria were used for chemical analysis. For the analysis of samples, the lyophilized samples were weighed to $0.010 \mathrm{~g}$ and transferred to a $5 \mathrm{ml}$ graduated flask. Mitochondrial samples were solved in tetrahydrofuran ( $\geq 99.9 \%$ (HPLC) Sigma-Aldrich, Germany) and transferred to a thermostatic ultrasound bath (Heidolph, Schwabach, Germany) and extracted for 15 minutes. The extracts were centrifugated for $5 \mathrm{~min}$. at $400 \mathrm{rpm}$. The supernatants obtained were removed from sediment into chemical glasses. The extracts were filtered through a Q-Max membrane filter $(25 \mathrm{~mm}$ in diameter, $0.45 \mu \mathrm{m}$ in pairs, Frisenette, Knebel, Germany). $850 \mu \mathrm{l}$ of solution from the prepared succinate extracts were taken and transfered to a $2 \mathrm{ml}$ chromatographic sample vial. Samples were evaporated to dryness with a gentle stream of nitrogen.

In order to prevent the absorption of succinic acid on the injector and to normalize the peak heights and area of the chromatograms, a solution of derivatizate bis- (trimethylsilyl) -trifluoroacetamide (BSTFA ( $\geq 99.9$ $\%$ Supelco, USA)) was used for fossil resin analysis. During derivatization, functional groups were modified in case to increase analyte stability and volatility. The general procedure of succinic acid chemical derivatization (Fig. 1).

The derivatization time (1h; 3h; $4 \mathrm{~h} ; 5 \mathrm{~h} ; 7 \mathrm{~h})$ and derivatization temperature $\left(70{ }^{\circ} \mathrm{C}\right)$ were selected. The all samples were capped, wrapped with parafilm tape, and heated at $70{ }^{\circ} \mathrm{C}$ to convert the targeted analytes to their trimethylsilyl derivatives. Other derivatized samples were kept at room temperature at the same exposure times. The evaluation of the GC-MS method has been performed by full scan (total ion current - TIC) using internal and external standards and by selected ion monitoring (SIM). 
<smiles>C[Si](C)(C)N=C(O[Si](C)(C)C)C(F)(F)F</smiles><smiles>CC[Si](C)(C)OC(=O)CCC(=O)O[Si](C)(C)C</smiles>

Fig. 1. Overall scheme of chemical derivatization of succinic acid by silylation using -bis- (trimethylsilyl) trifluoroacetamide (BSTFA)

The reaserch was done using methodology on SHIMADZU GC-MS-QP2010 Ultra chromatography system with Rxi-5ms (Restek Corporation) capillary column (30 m long, $0.25 \mathrm{~mm}$ outer diameter and $0.25 \mu \mathrm{m}$ liquid-stationary phase thickness) with a liquid stationary phase (5\% diphenyl and $95 \%$ polysiloxane). Carrier gas of chromatography - helium. Succinates were identified by comparison with database mass spectra of compounds or analyzing ions characteristic of mass spectra. For the identification of compounds, a computer uses the mass spectra measured by standard compounds. The spectrum of analytes is selected for comparison by a computer estimating the probability of the presence of the provided compounds.

The oven temperature was programmed from $45{ }^{\circ} \mathrm{C}$ for $2 \mathrm{~min}$, then $16{ }^{\circ} \mathrm{C} / \mathrm{min}$ to $250{ }^{\circ} \mathrm{C}$ for $1 \mathrm{~min}$, then $50{ }^{\circ} \mathrm{C} / \mathrm{min}$ to $315{ }^{\circ} \mathrm{C}$ and held constant for $5 \mathrm{~min}$. The injector temperature was $280{ }^{\circ} \mathrm{C}$, injection mode splitless (1 min), injection volume was $1 \mu \mathrm{L}$, split ratio $1: 20$, the ion source voltage $70 \mathrm{eV}$. Mass spectra scan range of $\mathrm{m} / \mathrm{z} 40-500$ amu with mass scan time 0.2 seconds, interface temperature $280^{\circ} \mathrm{C}$ (Table 1$)$.
Table 1

Temperature program gradient

\begin{tabular}{|c|c|c|}
\hline $\begin{array}{c}\text { Temperature gradient } \\
\left({ }^{\circ} \mathrm{C} / \mathrm{min}\right)\end{array}$ & $\begin{array}{c}\text { Temperature } \\
\left({ }^{\circ} \mathrm{C}\right)\end{array}$ & $\begin{array}{c}\text { Delay } \\
(\mathrm{min})\end{array}$ \\
\hline- & 45,0 & 2,00 \\
\hline 16,00 & 250,00 & 1,00 \\
\hline 50,00 & 315,00 & 5,00 \\
\hline
\end{tabular}

First, we examined the effect of temperature and derivatization time on the quantitative evaluation of succinate. The results showed that using derivatization with BSTFA at room temperature the amount of succinic acid was constantly changing (Fig. 2).

Therefore we applied the temperature mode. Using derivatization at $70{ }^{\circ} \mathrm{C}$ the maximal concentration of succinic acid $(2.98-2.96 \mu \mathrm{g} / \mathrm{ml})$ in mitochondrial samples was determined after 3-4 hours. Whereas when time of derivatization was prolonged, succinate concentration started to decrease (Fig. 3).

For measurements of succinate concentration in biological samples (mitochondria) we used optimal mode derivatization at $70{ }^{\circ} \mathrm{C}$ for $3-4$ hours (Fig. 4).

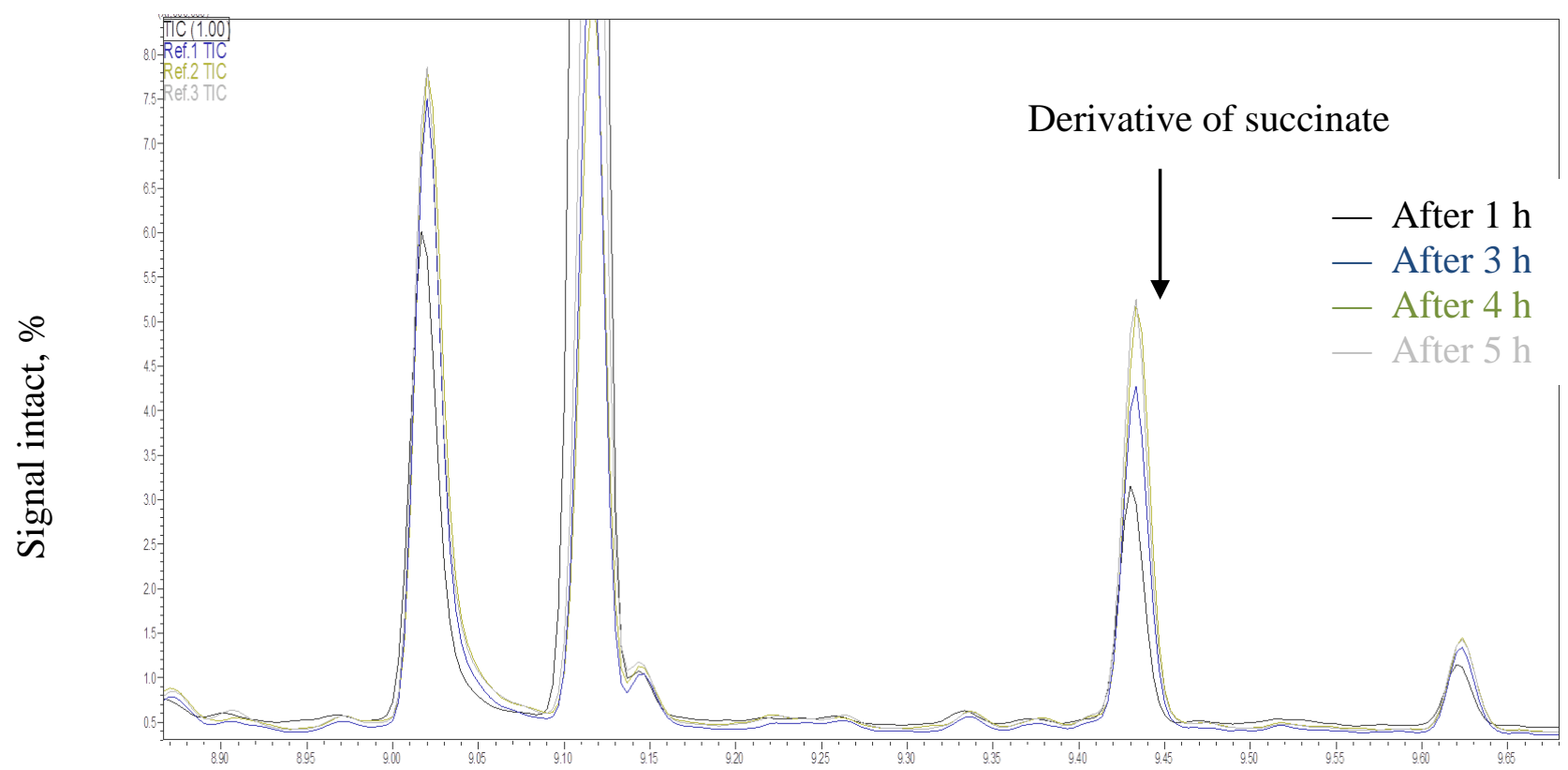

Fig. 2. Succinate standard chromatogram after derivatization at room temperature 


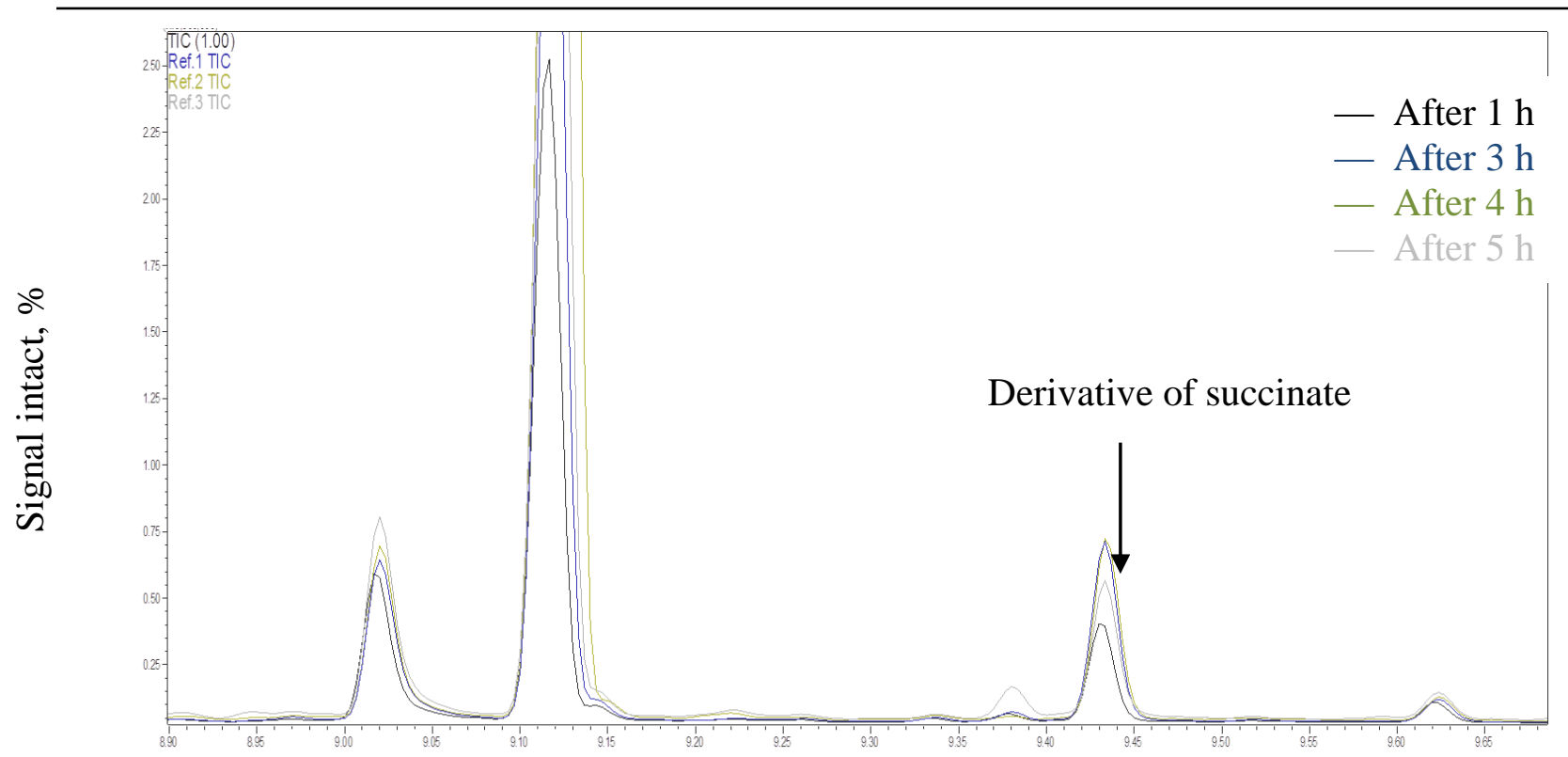

Fig. 3. Succinate standard chromatogram after derivatization at $70{ }^{\circ} \mathrm{C}$ temperature

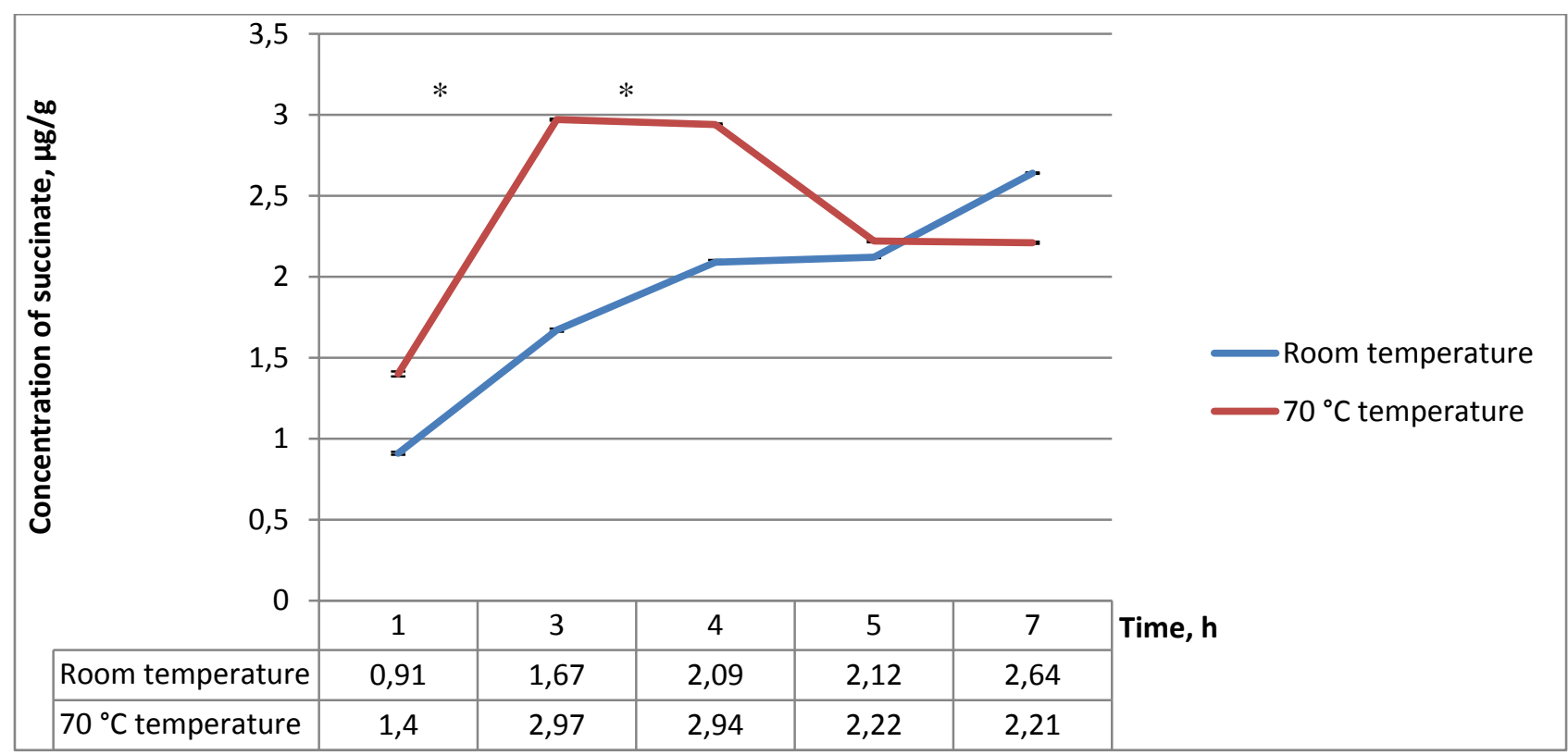

Fig. 4. The influence of temperature and time on derivatization

The DC-MS specific methodology using derivatization (BSTFA reagents) leads to identify succinic acid in organic compounds complex (ex. Fossil resins). A correctly obtained derivatization procedure and conditions can be used for rapid comparison of large sets of GC-MS data. Performed method will improve further investigations with succinic acid in biological samples or other metabolomics research. In addition, stable analyte result leads low detector noise and fouling. Finally, the effectiveness of the chromatography process were evaluated based on the concentrations of target organic acids found in the fossil resin samples.

Moreover, we applied the evaporation procedure for succinic acid solution. Caution must be exercised to prevent any water entering the samples as this will lead to hydrolysis of the BSTFA reagent and to prevent any of the targeted analytes from undergoing derivatization. Applying the GC-MS TIC procedure without evaporation succinate content in mitochondria was $73.55 \pm 104.01 \mu \mathrm{g} / \mathrm{g}$ and with the GC-MS SIM procedure without evaporation $162.13 \pm 34.59 \mu \mathrm{g} / \mathrm{g}$, respectively. The result of GC-MS TIC procedure with evaporated samples analysis was $43.18 \pm 20 \mu \mathrm{g} / \mathrm{g}$ and with GC-MS SIM procedure was $111.31 \pm 4.67 \mu \mathrm{g} / \mathrm{g}$, thus the distribution between the results was significantly lower. Moreover, GC - MS method allowed to diminish the lyophilized sample used for analysis by about 100 - folds, i.e. from $1000 \mathrm{mg}$ to $10 \mathrm{mg}$. Furthermore, this method is sensitive and selective.

\section{Conclusions from the conducted research} and prospects for further development of this field

In conclusion, the derivatization agent BSTFA, the derivatization time of 3-4 hours and derivatization temperature at $70{ }^{\circ} \mathrm{C}$ were selected as the optimal derivatization condition for quantification of succinic acid by GC/MS in biological samples. The results show that GCMS SIM method with evaporation was the most effective to quantify succinate in biological samples after ische- 
mia/reperfusion injury. Selected ion monitoring (SIM) allowed to monitor a subset of fragments with their related mass values in a certain retention time (RT) range for a set of targets. This targeted method to lead to increased sensitivity compared to full scan, as the mass spectrometer monitors a small fraction of the mass range in the former case. The results suggest that the method could be usefully integrated into biochemistry studies of mitochondrial metabolites. This method will be used in our further investigations with succinate in biological sam- ples after ischemia/reperfusion injury in mitochondrial and cytosolic fractions. The procedure of method validation is going to be performed. We describe DC-MS method and their application for detection of succinate amount in mitochondria from kidney tissue.

DC - MS has several advantages for measurements of succinate concentration in small kidney tissue samples (lyophilized mitochondria). The method can be applied in small pieces of tissue - biopsy samples, tissues from various organs.

\section{References}

1. Orata F. Derivatization Reactions and Reagents for Gas Chromatography Analysis // Advanced Gas Chromatography Progress in Agricultural, Biomedical and Industrial Applications. InTech, 2012. doi: http://doi.org/10.5772/33098

2. Lynch T. P., Grosser A. P. K. Inlet Derivatisation for the GC Analysis of Organic Acid Mixtures // Chromatography and Separation Technology. 2000. Vol. 13. P. 12-15.

3. Comparison of MTBSTFA and BSTFA in derivatization reactions of polar compounds prior to GC/MS analysis / Schummer C. et. al. // Talanta. 2009. Vol. 77, Issue 4. P. 1473-1482. doi: http://doi.org/10.1016/j.talanta.2008.09.043

4. Dunn W. B., Hankemeier T. Mass spectrometry and metabolomics: past, present and future // Metabolomics. 2013. Vol. 9 , Issue 1. P. 1-3. doi: http://doi.org/10.1007/s11306-013-0507-z

5. Extraction and GC/MS Analysis of the Human Blood Plasma Metabolome / Jiye A. et. al. // Analytical Chemistry. 2005. Vol. 77, Issue 24. P. 8086-8094. doi: http://doi.org/10.1021/ac051211v

6. Yip L. Y., Yong Chan E. C. Gas Chromatography/Mass Spectrometry-Based Metabonomics // Proteomic and Metabolomic Approaches to Biomarker Discovery. Elsevier, 2013. P. 131-144. doi: http://doi.org/10.1016/b978-0-12-394446-7.00008-x

7. An Enhanced GC/MS Procedure for the Identification of Proteins in Paint Microsamples / Fico D. et. al. // Journal of Analytical Methods in Chemistry. 2018. Vol. 2018. P. 1-8. doi: http://doi.org/10.1155/2018/6032084

8. New techniques of on-line biological sample processing and their application in the field of biopharmaceutical analysis / Peng J. et. al. // Acta Pharmaceutica Sinica B. 2016. Vol. 6, Issue 6. P. 540-551. doi: http://doi.org/10.1016/j.apsb.2016.05.016

9. Ding W.-H., Chiang C.-C. Derivatization procedures for the detection of estrogenic chemicals by gas chromatography/mass spectrometry // Rapid Communications in Mass Spectrometry. 2002. Vol. 17, Issue 1. P. 56-63. doi: http://doi.org/10.1002/rcm.819

10. Alkylation or Silylation for Analysis of Amino and Non-Amino Organic Acids by GC-MS? / Villas-Bôas S. G. et. al. // Metabolites. 2011. Vol. 1, Issue 1. P. 3-20. doi: http://doi.org/10.3390/metabo01010003

11. Ischaemic accumulation of succinate controls reperfusion injury through mitochondrial ROS / Chouchani E. T. et. al. // Nature. 2014. Vol. 515, Issue 7527. P. 431-435. doi: http://doi.org/10.1038/nature13909

12. Ozpinar A., Weiner G. M., Ducruet A. F. Succinate: A Promising Therapeutic Target for Reperfusion Injury // Neurosurgery. 2015. Vol. 77, Issue 6. P. 13-14. doi: http://doi.org/10.1227/01.neu.0000473807.30361.29

13. Determination of Impurities in Bioproduced Succinic Acid / Rousova J. et. al. // Journal of Chromatography \& Separation Techniques. 2014. Vol. 6, Issue 2. doi: http://doi.org/10.4172/2157-7064.1000264

14. Tretter L., Patocs A., Chinopoulos C. Succinate, an intermediate in metabolism, signal transduction, ROS, hypoxia, and tumorigenesis // Biochimica et Biophysica Acta (BBA) - Bioenergetics. 2016. Vol. 1857, Issue 8. P. 1086-1101. doi: http://doi.org/ 10.1016/j.bbabio.2016.03.012

Дата надходження рукопису 12.06.2018

Laurynas Jarukas, PhD, Department of Analytical and Toxicological Chemistry, Medical Academy of Lithuanian University of Health Sciences, Eivenių g. 4, LT-50161 Kaunas, Lithuania

E-mail: laurynas.jarukas@1smuni.lt

Justina Kamarauskaitė, Department of Pharmacognosy, Medical Academy of Lithuanian University of Health Sciences, Eiveniu g. 4, LT-50161 Kaunas, Lithuania

E-mail: justina.kamarauskaite@fc.lsmuni.lt

Mindaugas Marksa, PhD, Department of Analytical and Toxicological Chemistry, Medical Academy of Lithuanian University of Health Sciences, Eivenių g. 4, LT-50161 Kaunas, Lithuania

E-mail: mindaugas.marksa@1smuni.lt

Sonata Trumbeckaitė, PhD, Associate Professor, Department of Pharmacognosy, Medical Academy of Lithuanian University of Health Sciences, Eiveniu g. 4, LT-50161 Kaunas, Lithuania

E-mail: sonata.trumbeckaite@1smuni.lt

Rasa Banienè, PhD, Associate Professor, Neuroscience Institute, Lithuanian University of Health Sciences, Eiveniu g. 4, LT-50161 Kaunas, Lithuania

E-mail: rasa.baniene@1smuni.lt

Liudas Ivanauskas, $\mathrm{PhD}$, Associate Professor, Department of Analytical and Toxicological Chemistry, Medical Academy of Lithuanian University of Health Sciences, iveniu g. 4, LT-50161 Kaunas, Lithuania

E-mail: liudas.ivanauskas@1smuni.lt 